\title{
Quality Improvement of RCC Structure of Residential Building by Using Quality Performed Assessment Method.
}

\author{
Manisha Bhalerao ${ }^{1}$ \\ $P G$ Student (Construction and Management) ${ }^{1}$ \\ Department of Civil Engineering ${ }^{1}$ \\ Email: manishabhalerao.mrb@gmail.com ${ }^{1}$
}

\begin{abstract}
In modern construction market, the main phases of a project can be described as: conceptual planning, feasibility of project in all aspects, design, procurement, construction, acceptance, operation and maintenance. Poor quality construction resulted into loss of contractor, as well as project stakeholders. Favorable outcome of construction project is depending on effective use of schedule, cost and quality. Existing tools are enable to monitored time and cost of construction project but most of project stakeholders do not have any concern about the quality of a construction project. Hence this research focus to study importance of quality management system in construction industry, to study quality performed assessment method and to validate Quality Performed Assessment Method based on CONQUAS rating system to measure the quality of RCC structure of residential building. There are two stages of study, in the first stage study of evaluation of QPAM computation sheet. In the second stage validation of QPAM computation sheet on case study. Quality performed assessment method is a single monitoring and reporting and can highlight the important notification regarding quality of construction project. Project stakeholders enables continuous improvement from a very initial stage of project. Project execution team can easily take review on construction activity on a single click and can keep in following up with contractor's work quality. Also, project stakeholders enable to check cost overrun, time as well as quality of project. Form this study project execution team can easily compare the quality of construction activity. Continuous improvement in the construction activity can be achieved by using QPAM.
\end{abstract}

Index Terms- Iron Triangle, CONQUAS, QPAM, Quality management system, Quality Performed.

\section{INTRODUCTION}

Continuous improvement of quality should be a culture of an organization involving all the parties. Achievement of required quality level means to reduce the wastage in the system and process of an organization and ensures the use of minimum financial level. Use of quality management system to continuous improvement is the best practice now a days. In modern construction technique industries now turning to use QMS at maximum level to increase productivity of the employees, reduce wastage and minimum use of economy. Quality management system works on all these success factors of an organization i.e time, cost and quality. (Ron Basu, 2014; Hong Yeow Ong; Chen Wang; and Nurshuhada Zainon, 2017; Abdul Halim bin Ahmad 2018.) Provisio 2018.).

Construction industry plays an important role in the development of any country. The development of construction industry depends on the quality of construction projects. Quality is one of the critical factors in the success of construction projects. Improvement in the quality of construction projects is linked with quality management in the project life cycle. Although quality management at every stage of project life cycle is important but the quality management at the execution (construction) stage contributes significantly on final quality outcome of construction projects. Quality of construction projects, as well as project success, can be regarded as the fulfilment of expectations (i.e. the satisfaction) of the project participants (H.Mallawaarachchi and S. Senaratne, 2015). The construction industry in India has been struggling with quality issues for many years. A significant amount of the budget is spent each year on infrastructure and other development projects. Since the quality outcomes of the projects are not according to required standards. In construction industry, residential projects are most common where quality conformance is very important factor to fulfillment of customer's requirements. Nowadays concepts such as sustainability, environmental impact, and social impact, customer's expectations, and safety might be considered as success factors, project success has long been considered the ability to fall within

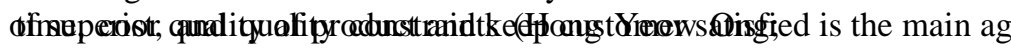
Chen Wang; and Nurshuhada Zainon, 2017). The existing method of construction budget calculation does not consider the quality change (trend change) in residential construction, so that value added is calculated unrealistically low, which in turn results in low productivity value. This results into number of revisions in reported cost increases per unit can be overestimated as the index does not take into account quality improvements over time (Lena Borg and HanSuck Song). In a NEDO (National Economic Development Office), London survey aimed at improving methods of quality control for building works it was found that "design" and "poor workmanship in the construction process" combined 
International Journal of Research in Advent Technology, Vol.7, No.5, May 2019

\section{E-ISSN: 2321-9637 \\ Available online at www.ijrat.org}

to form more than $90 \%$ of the total failure events. Therefore this study aims to study quality performance assessment method developed by using CONQAUS to measure the quality of RCC structure of residential building managing all three constraints i.e time, cost and quality. There is no such single tool to measure quality of construction project. And commercial tools are mostly focus on cost and time only to measure success. The goal of this research is to study importance of quality management of RCC structure of residential building and newly developed quality extension QPAM, and to assess the quality performance of RCC structure.

\section{IMPORTANCE OF QUALITY MANAGEMENT SYSTEM}

The definition of quality is differed slightly from person to person, but they remained in two basic categories are same universally conformance to requirements; and customer satisfaction. Implementation of quality is each and every ones responsibility and efforts will results into great achievement. The above two definitions are interdependent and are related. "Quality management" ensures superior quality products and services. It is important for customer satisfaction which eventually leads to customer loyalty. Use of QMS can be achieved required quality level from a very initial stage of project. QMS enables to take review and progress report chart of construction project on one click. Use of quality management tools ensures increased optimism in the documentation, revenues and higher productivity for the organization. It prevents wastage in the system and material inventory of an organization. Quality

Management enables close communication among each stakeholder of an organization. Quality management systems increases productivity of each and every participant in the project. Use of quality management system ensures everyone to achieve required level of quality. Quality achievement at required level gives a long term success in terms of customer satisfaction and business growth. Quality management aspects are essential in every stage. Training, seminars etc.(Ede A.N.,2011) can be given to whom involved directly or indirectly to the construction project developed awareness among the project stakeholders (H. Mallawaarachchi and S. Senaratne, 2015; Abdul Halim bin Ahmad, 2018.). Construction project in its life span goes from different phases. Design and Construction are the two most important phases of project which affect the overall quality of the project. Quality of construction projects is regarded as the fulfillment of expectations of the project stakeholders by optimizing there satisfaction and increasing productivity (Ron Basu, 2014).

\section{PROBLEM STATEMENT}

Existing quality assessment tool are focused on end products. In manufacturing industry where a good quality of setup of machineries can give a required quality product but it is not possible in construction industry. Hence it is very important to assess the quality of construction activity in a very early stage so that stakeholders can be achieved required quality level of product. For example, when a slab is constructed, CONQUAS will be used to assess the quality of the slab, but the installation process of the slab is not assessed. Although there bar and formwork will be assessed separately, it does not cover the concrete vibration process and the concrete curing period. Therefore, any mistake during the installation process will not be detected and no immediate action can be taken to identify those mistakes and can be removed before casting of slab. Failure of quality in construction industry can occur at any stage. For example, if the quality of drawing or specification is not maintained then execution will be hampered, etc. If quality assessment after execution of activity may lost important information. The errors in the construction project occur frequently and it can be costly to contractor and owner also. (Haverila and Fehr 2016) Expenses of rework is more. Quality measurement should also be conducted during the early stages (Basu 2014). Hence, in this study we are developing a quality assessment method to check the quality of work in a very stage of execution.

\subsection{Objective of the Study}

(1) To study the importance of Quality management system in construction industry.

(2) To study the Quality Performed Assessment Method of Quality Management (QPAM).

(3) To assess the quality performed of RCC structure of residential building by using QPAM.

\subsection{Scope of the Study}

This study was conducted in Nashik, India. QPAM is applied construction site where RCC work is started. There are total 43 towers of seven storied. All are residential buildings. Project included low budget two and three BHK flats. But the quality of should be up to the required level. The study included assessment of RCC structure only and limited to residential project. It is not done for commercial and infrastructure project.

\section{CONQUAS AND QPAM}

This research aims to validate quality as a new extension to measure the success of the construction project. The proposed new value quality performed (QP) which is the percentage of the to-date attained quality performed by the project stakeholders. Quality performed is the mean quality that has been achieved by construction activity. For example, if the quality of formwork achieved 6 points out of a 10-point score range, those 6 points are the $\mathrm{QP}$ value. To measure 
QP, CONQUAS is the foundation, as per specifications given the CONQUAS checklists are prepared. Weightage system is same as per CONQUAS, but the assessment approach is totally different. Assessment method is the only difference between CONQUAS and QPAM, but the standards are the same. This is because CONQUAS is accepted and recognized by worldwide AEC projects. QPAM's weightage system is easily understandable than the CONQUAS weightage system. COQUAS have different rating system for different types of buildings. While in QPAM, to give point for an activity or event we have developed checklist on the basis of standards and specification of the activity. Checklist is also one of the quality measuring tool used by and accepted universally by AEC project's stakeholders. And it is easy measure exact quality of the activity.

Table 1. Weightage System for Quality Performed

Assessment System.

\begin{tabular}{|c|c|c|}
\hline \multicolumn{3}{|c|}{$\begin{array}{c}\text { Weightage System For Quality Performed } \\
\text { Assessment Method }\end{array}$} \\
\hline \multirow{2}{*}{$\begin{array}{l}\text { Sr. } \\
\text { No. }\end{array}$} & \multirow[b]{2}{*}{ Type Of Work } & Weightages \\
\hline & & $\begin{array}{l}\text { Residential } \\
\text { Building \% }\end{array}$ \\
\hline 1.0 & Architectural Work & 50.0 \\
\hline 1.1 & Floor & 7.0 \\
\hline 1.2 & Internal Wall & 8.0 \\
\hline 1.3 & Ceiling & 5.0 \\
\hline 1.4 & Door & 5.0 \\
\hline 1.5 & Window & 5.0 \\
\hline 1.6 & Component & 3.0 \\
\hline 1.7 & Roof & 5.0 \\
\hline 1.8 & Waterproofing & 4.0 \\
\hline 1.9 & External Wall & 5.0 \\
\hline 1.1 & $\begin{array}{l}\text { External Work (Such as } \\
\text { walkway, Car park, } \\
\text { Fencing, Etc.) }\end{array}$ & 3.0 \\
\hline 2.0 & Structural Work & 40.0 \\
\hline 2.1 & Formwork & 7.0 \\
\hline 2.2 & Rebar & 8.0 \\
\hline 2.3 & Finished Concrete & 8.0 \\
\hline 2.4 & Concrete Quality & 6.0 \\
\hline 2.5 & $\begin{array}{ll}\text { Steel } & \text { Reinforcement } \\
\text { Quality } & \end{array}$ & 5.0 \\
\hline 2.6 & Testing & 6.0 \\
\hline 3.0 & M \& E Work & 10.0 \\
\hline 3.1 & Electrical & 2.0 \\
\hline 3.2 & Fire Protection & 3.0 \\
\hline 3.3 & Plumbing \& Sanitary & 3.0 \\
\hline 3.4 & Basic Fittings & 2.0 \\
\hline
\end{tabular}

\section{PROCEDURE OF QUALITY PERFORMED ASSESSMENT METHOD}

QPAM included in the day to day activity of the project execution team. So it is not necessary to appoint an outsourced assessor. Project managers, site engineers, quality engineers are able to check the quality level of an activity. Request for inspection practice is used to inspect the activity accordance with the drawings, specification and standard checklists. RFI is used in AEC projects in most of the project. This practice is followed by most of organization to ask consultants on site to check the event or an activity. A contractor will issue a RFI to relevant consultant or consultant's representative or site engineers, Project manager, quality engineers etc. to inspect the work done and the preparation work before proceeding. Once the work done by contractor is approved then he allowed to proceed further work. If it is not approved then he has to dismantle the work done by him and again start to work with the precision. Practicing RFI as a quality checking tool, it will help to continuous improvement during the construction implementation stage. Because there are many repeated works conducted in the same project like formwork, concreting, steel cutting etc. In case of using RFI, the first mistake is detected for such work, the contractor can be immediately rectify the mistake and work according to standards.

Following are the checklist we have used to check the RCC structure of residential building.

(1) Formwork: In the formwork checklist following checks are define. After submitting RFI from contractor to site engineer or quality engineer. Site engineer and quality engineer will check the work preparation of formwork as per the following checklists. If it is passed in the first inspection only then there will be no need of second inspection. But it is fail in the first inspection then contractor have to clear the issues and resubmit the RFI again second inspection will be done by site engineer and quality engineer and give points as per the checklists.

(2) Rebar: In this activity, bar bending schedule, cutting of bars, bar bent tolerance, drawing specifications etc. studied by contractor and site engineer. Control in wastage of steel and cost saving is also an important concern behind the checking of rebar. Laying of steel is as per drawing or not, spacing of stirrups, lap length, placing of cover blocks etc. checks are included in the rebar checklists. This inspection is done in presence of structural consultant, site engineer and quality engineer.

(3) Steel Reinforcement: When steel is received at site, it is checked by quality engineer and this document is submitted by the quality engineer. All physical tests like color, rust free, length and size of bar, tor mark, grade of steel etc. checks conducted at site. And report is prepared by 


\section{Available online at $w w w . i j r a t . o r g$}

quality engineer. If the tests are failed then steel is returned to supplier/contractor with the checklist.

(4) Concrete: Quality of the concrete is checked as per following checklists. Checklist included grade of concrete, W/C ratio, slump of concrete, placing time of concrete, transportation of concrete etc. checked by site engineer and quality engineer as per checklists and standards and marks given to the contractor.

(5) Before/After concreting: Checklists consist checking of machineries \& equipment to be used by contractor, weigh batcher, concrete mixer, vibrator, W/C ratio, foam finish, slump etc. and this checklist recorded and maintained by the quality engineer.

Table (2) shows conceptual model of QPAM. There are some basic rule of computation sheet. QPAM proposed to use Excel sheet for computation. After filling the checklist the final score of quality is calculated and quality performed (QP) will represent in QPAM computation sheet. All construction activity to be inspected will have 10 marks is the highest score and 0 is the lowest score. The passing score is 9 marks. Any score below 9 marks will require reinspection. One mark will be deducted for each failure; hence, if there are more failure in quality, the marks will be lower. If there are more than two noncompliance then quality of an activity is relatively low. The division of marks is divided in to $60 \%$ and $40 \%$. During the inspection, $60 \%$ of the mark is for first inspection plus $40 \%$ of the mark is for second inspection. Based on the above rules QPAM conceptual model is showing alternating QP score.

(1) During the inspection, first time pass 9 marks is given.

(2) If it fails, 7 marks is given in the first attempt and 9 marks is given when it passed. 
International Journal of Research in Advent Technology, Vol.7, No.5, May 2019 E-ISSN: 2321-9637

Available online at www.ijrat.org

\begin{tabular}{|c|c|c|c|c|c|c|c|c|c|c|c|c|c|c|c|c|c|c|c|c|c|c|}
\hline & 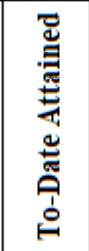 & 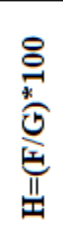 & & & & & & & & & & & $\begin{array}{l}\infty \\
\text { ă }\end{array}$ & & & & & & & & & \\
\hline & 青总 & \&ें & \multicolumn{20}{|c|}{$\begin{array}{l}8 \\
\stackrel{+}{+}\end{array}$} \\
\hline & 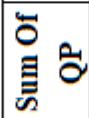 & $\stackrel{\circ}{\text { I }}$ & \multicolumn{20}{|c|}{ î } \\
\hline & 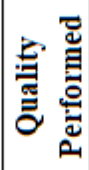 & $\stackrel{\stackrel{0}{a}}{*}$ & \multicolumn{3}{|c|}{ ○̊ } & \multicolumn{4}{|c|}{ స్ } & \multicolumn{3}{|c|}{ స్ } & \multicolumn{3}{|c|}{$\begin{array}{l}\text { to } \\
\text { in }\end{array}$} & \multicolumn{4}{|c|}{ ঙิ } & \multicolumn{3}{|c|}{ 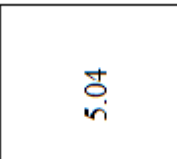 } \\
\hline \multirow{11}{*}{\multicolumn{2}{|c|}{ | }} & 윽 & $r$ & 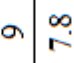 & ए & $n$ & $\sigma:$ & : & む. & . & $a \mid \infty$ & ప & -1 & $a \mid \infty$ & 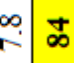 & 5 & a & $\stackrel{\infty}{\stackrel{\infty}{\sim}}$ & $\infty$ & $a$ & $\stackrel{\infty}{\sim}$ & あ \\
\hline & & $a$ & a. & - 1 & & a & 0. & $a$ & & o. & 0.0 & & $a$ & $\circ 0$ & a & $a$ & 0 & $a$ & $\circ$ & 0 & $a$ & \\
\hline & & $\infty$ & $r$ & $a \mid \stackrel{\infty}{\stackrel{\infty}{r}}$ & & $n$ & a: & $\begin{array}{l}\infty \\
r \\
r\end{array}$ & & 7 & 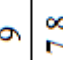 & & $r$ & $a \mid \begin{array}{l}\infty \\
n\end{array}$ & $\begin{array}{l}\infty \\
r \\
r\end{array}$ & $r$ & $a$ & $\stackrel{\infty}{\infty}$ & $r$ & $a$ & $\stackrel{\infty}{\sim}$ & \\
\hline & & $r$ & $a$ & - 0 & & a & 00 & $a$ & & a. & 0.0 & & $a$ & $\circ \mid 0$ & a & $a$ & 0 & a & $\circ$ & 0 & $a$ & \\
\hline & & $\bullet$ & - & 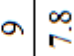 & & -1 & a: & . & & -1 & $a \mid \infty$ & & $r$ & $a \mid \infty$ & . & $r$ & $a$ & \begin{tabular}{l}
$\infty$ \\
\hdashline \\
\hdashline
\end{tabular} & $r$ & $a$ & $\stackrel{\infty}{\sim}$ & \\
\hline & & in & $a$ & - 1 & & a & 0. & a & & a. & $\circ 0$ & & $a$ & $\circ 0$ & a & $a$ & 0 & $a$ & $\circ$ & 0 & $a$ & \\
\hline & & + & - & $a$ & & - & $a:$ & . & & $r$ & $\sigma \mid \infty$ & & $r$ & $a \mid \infty$ & . & $r$ & $a$ & \begin{tabular}{l}
$\infty$ \\
\hdashline \\
$\sim$
\end{tabular} & $r$ & $a$ & $\stackrel{\infty}{\sim}$ & \\
\hline & & $m$ & $a$ & - 10 & & a & 0 & $a$ & & a. & $\circ 0$ & & $a$ & $\circ 0$ & a & $a$ & 0 & $a$ & $\circ$ & 0 & $a$ & \\
\hline & & $N$ & $r$ & 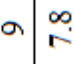 & & - & $a:$ & 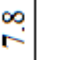 & & 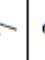 & $a \mid \infty$ & & $r$ & $a \mid \infty$ & 我 & $r$ & $a$ & $\begin{array}{l}\infty \\
\sim \\
\sim\end{array}$ & $r$ & $a$ & $\stackrel{\infty}{r}$ & \\
\hline & & - & a & - 1 & & a & $\circ$ & $a$ & & a. & $\circ .0$ & & $a$ & $\circ 0$ & $a$ & $a$ & 0 & $a$ & & 0 & $a$ & \\
\hline & & 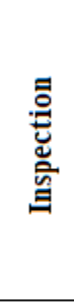 & 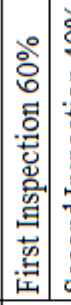 & 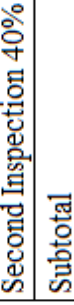 & & 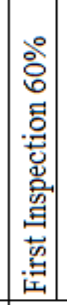 & 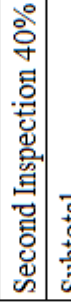 & 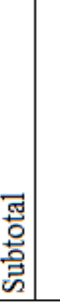 & & : & 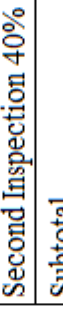 & & 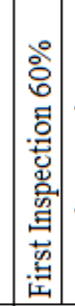 & 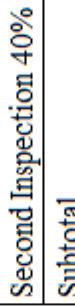 & 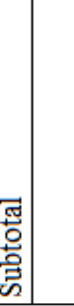 & 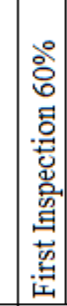 & 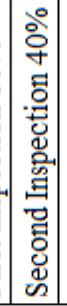 & 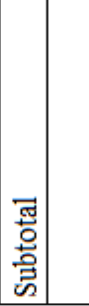 & & 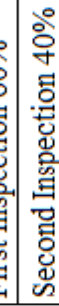 & 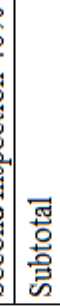 & \\
\hline & $\pi$ & 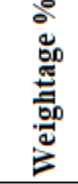 & \multicolumn{3}{|c|}{$\stackrel{\circ}{\circ}$} & \multicolumn{4}{|c|}{ ळे } & \multicolumn{3}{|c|}{ ळे } & \multicolumn{3}{|c|}{ ذి } & \multicolumn{3}{|c|}{ ì } & & \multicolumn{3}{|c|}{ ذें } \\
\hline \multirow{2}{*}{\multicolumn{2}{|c|}{ 䓌 }} & 窇 & \multicolumn{3}{|c|}{$\begin{array}{l}\text { 产 } \\
\text { 言 } \\
\text { 宫 }\end{array}$} & \multicolumn{4}{|c|}{ 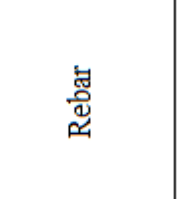 } & \multicolumn{3}{|c|}{ 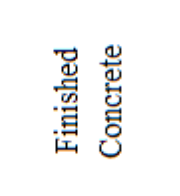 } & \multicolumn{3}{|c|}{ 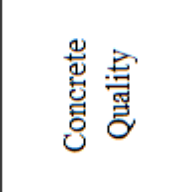 } & \multicolumn{3}{|c|}{ 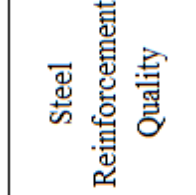 } & & \multicolumn{3}{|c|}{ 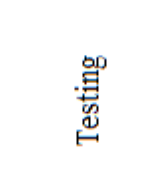 } \\
\hline & & $\dot{\text { के }}$ & \multicolumn{3}{|c|}{$\rightarrow$} & \multicolumn{4}{|c|}{$N$} & \multicolumn{3}{|c|}{$m$} & \multicolumn{3}{|c|}{+} & \multicolumn{4}{|c|}{ in } & \multicolumn{3}{|c|}{0} \\
\hline
\end{tabular}




\section{CASE STUDY:}

The aim of this research is to validate the functionality of quality performed assessment method on a real construction project. The information regarding project is given above, project X implemented QPAM as per given procedure.

(1) RCC contractor finished a preparation work and submitted the RFI form to site engineer.

(2) The representative of structural consultant and site engineer, quality engineer carried out an inspection in accordance with the GFCs, specifications of material and checklists.

(3) The consultants and site engineers gave a QP score as per the CONQUAS's standard, and the QP score was recorded in the QPAM computation excel sheet.
QPAM computation sheet contained huge data so it becomes difficult to present to all stakeholders. QPAM computation sheet contained each QP detail. Hence, a summary sheet is provided to all project stakeholder where they can understand quality performance of the construction site. Sharing of summary sheet of QPAM with all project stakeholder, they can easily monitored and reviewed. Table no.3 is the summary sheet of QPAM in which we have calculated quality score for RCC substructure i.e footing and columns above.

Table no.3 QPAM summary sheet.

\begin{tabular}{|c|c|c|c|c|c|c|c|}
\hline Sr.No. & Description & Weightage & Score & $\begin{array}{l}\text { Achievable } \\
\text { Score }\end{array}$ & Percentage & $\begin{array}{c}\text { Quality } \\
\text { Performed }\end{array}$ & $\begin{array}{l}\text { Achievable } \\
\text { Weightage }\end{array}$ \\
\hline & $\begin{array}{c}\text { RCC Substructure } \\
\text { (Month 1st) }\end{array}$ & (a) $\%$ & (b) & (c) & $(d=b / c)$ & $\begin{array}{c}(e= \\
a * d) \%\end{array}$ & f\% \\
\hline 1.0 & Structural Work & 40.0 & & & & & \\
\hline 1.1 & Formwork & 7.0 & 78.8 & 100 & 78.8 & 5.52 & 7.0 \\
\hline 1.2 & Rebar & 8.0 & 77.2 & 100 & 77.2 & 6.18 & 8.0 \\
\hline 1.3 & Finished Concrete & 8.0 & 81 & 100 & 81.0 & 6.48 & 8.0 \\
\hline 1.4 & Concrete Quality & 6.0 & 85.2 & 100 & 85.2 & 5.11 & 6.0 \\
\hline 1.5 & $\begin{array}{l}\text { Steel Reinforcement } \\
\text { Quality }\end{array}$ & 5.0 & 75.6 & 100 & 75.6 & 3.78 & 5.0 \\
\hline 1.6 & Testing & 6.0 & 80.4 & 100 & 80.4 & 4.82 & 6.0 \\
\hline & Total & & & & & 31.89 & 40.0 \\
\hline \multicolumn{2}{|c|}{$\begin{array}{l}\text { To date attained(total e/total } \\
\text { f) }\end{array}$} & & & & & & 79.7 \\
\hline
\end{tabular}

Graph no.1

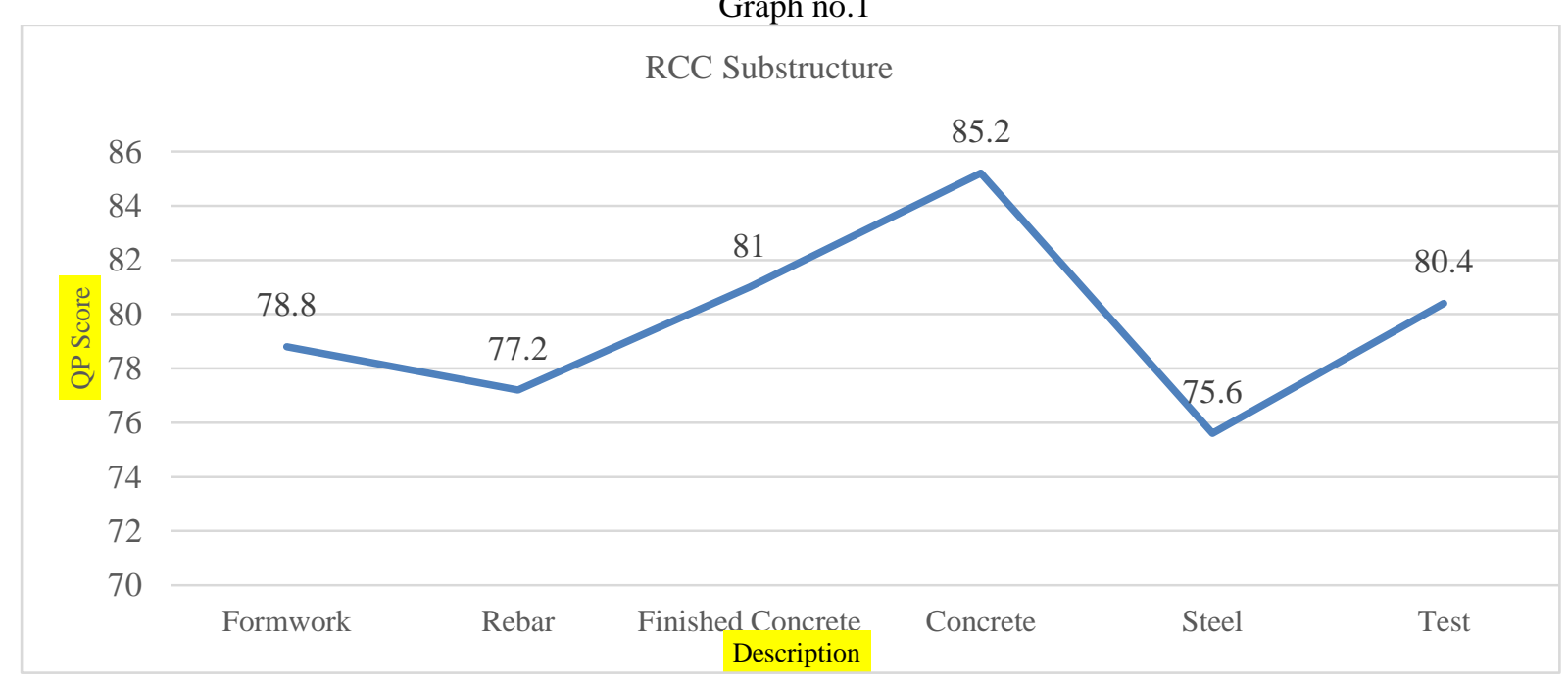

Graph no.1 represents the quality score of RCC substructure of residential building. Graph shows the sudden increase or decrease in the quality. Project stakeholders can monitored achieved quality of structure easily. Analysis of graph is done by project stakeholders to improve the quality of project. QPAM
Solved many problems that were unable to be solved by project execution team. The mistakes in the work can be easily determined by contractors as well as project stakeholders so that it is possible to remove or repair it on the same time. Table no. 4 shows comparison of quality score achieved. 
International Journal of Research in Advent Technology, Vol.7, No.5, May 2019 E-ISSN: 2321-9637

Available online at www.ijrat.org

\begin{tabular}{|c|c|c|c|c|c|c|c|c|c|c|c|}
\hline \multirow{5}{*}{ 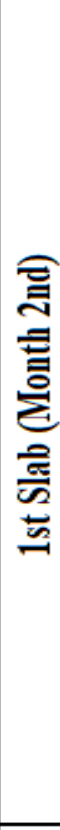 } & 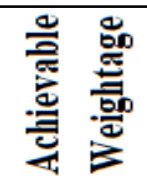 & \&े & & 움 & O. & O. & O & in & ㅇ. & 㑏 & $\stackrel{2}{\infty}$ \\
\hline & 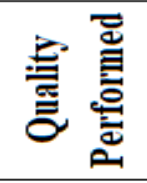 & $\begin{array}{c}\stackrel{0}{0} \\
\substack{* \\
\text { co } \\
11 \\
0}\end{array}$ & & $\begin{array}{l}2 \\
\vdots \\
\end{array}$ & $\begin{array}{l}2 \\
\\
\end{array}$ & 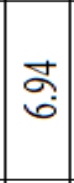 & 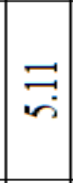 & 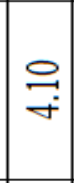 & $\sqrt[5]{8}$ & $\begin{array}{c}\vec{b} \\
\vec{m}\end{array} \mid$ & \\
\hline & 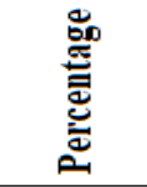 & 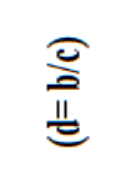 & & 络 & $\stackrel{ }{ \pm}$ & $\left|\begin{array}{l}\infty \\
\infty \\
\infty\end{array}\right|$ & 年 & i & ช్రా & & \\
\hline & 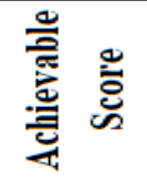 & () & & 응 & 이 & 음 & 으 & 으 & ఏ & & \\
\hline & 总 & ఏ & & 水 & \pm & \begin{tabular}{|l|}
$\infty$ \\
$\infty$ \\
$\infty$
\end{tabular} & $\begin{array}{c}n \\
\infty \\
\infty \\
\end{array}$ & $\infty$ & حૈ: & & \\
\hline \multirow{8}{*}{ 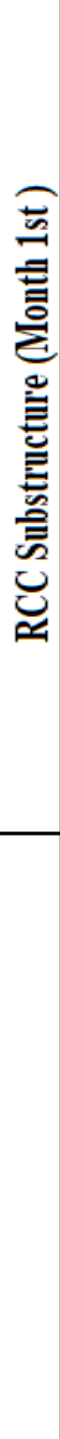 } & 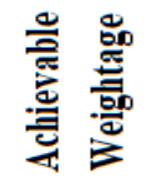 & \&े & & 욱. & $\stackrel{0}{\infty}$ & $\begin{array}{l}0 \\
\infty\end{array}$ & O & in & ㅇ. & 㑏 & $\approx$ \\
\hline & 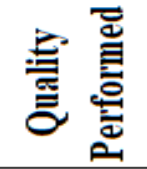 & 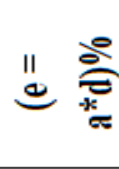 & & 胥 & $\frac{\infty}{0}$ & $\begin{array}{l}\text { o } \\
\text { bे }\end{array}$ & $\Rightarrow$ & $\underset{\sim}{\infty}$ & $\begin{array}{c}\mathscr{S} \\
\stackrel{+}{+}\end{array}$ & 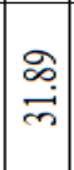 & \\
\hline & 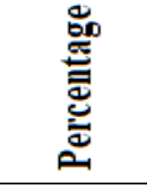 & 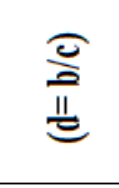 & & $\mid \begin{array}{l}\infty \\
\infty \\
\infty \\
\infty\end{array}$ & $\stackrel{\mathfrak{Z}}{\mathrm{E}}$ & $\left|\begin{array}{c}0 \\
\dot{\infty}\end{array}\right|$ & $\mid \begin{array}{c}n \\
-3 \\
\infty\end{array}$ & 焉 & 官 & & \\
\hline & 㟒 & () & & 응 & 응 & 응 & 응 & 으 & ఏ & & \\
\hline & 总 & ) & & $\begin{array}{l}\infty \\
\infty \\
\infty\end{array}$ & $\stackrel{\mathfrak{Z}}{\mathrm{E}}$ & $\vec{\infty}$ & 弪 & $\stackrel{\circ}{\circ}$ & 灾 & & \\
\hline & 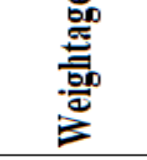 & ঐ & $\mid$ & 욱 & O. & $\begin{array}{l}0 \\
\infty\end{array}$ & O. & in & : & & \\
\hline & 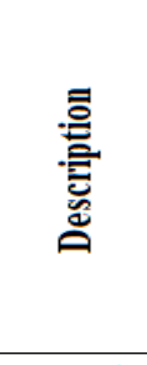 & & 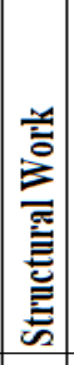 & 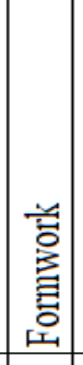 & 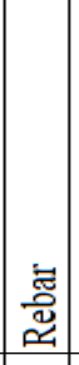 & 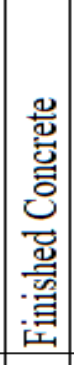 & 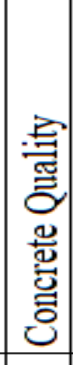 & 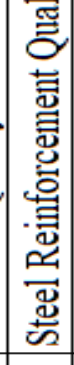 & 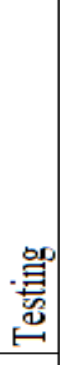 & 퐁 & 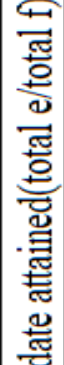 \\
\hline & $\dot{\bar{n}} \dot{0}$ & & 엄 & $\exists$ & 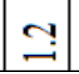 & 3 & 艺 & $\because$ & $\stackrel{-}{-}$ & & 总 \\
\hline
\end{tabular}


International Journal of Research in Advent Technology, Vol.7, No.5, May 2019

E-ISSN: 2321-9637

Available online at www.ijrat.org

\section{CONCLUSION}

As observed in many construction companies cost and time are the most important factor to calculate project success but not quality. On the other hand researchers developed a standard set to gauge the quality of construction activities. A new quality assessment extension Quality Performed Assessment Method was developed by using CONQUAS as part of its base, is used to validate the RCC structure of construction project. Throughout a whole validation processes, including the conceptual model, and real case studies of QPAM were proven beneficial to construction industry. The project stakeholders enables to measure quality achievement of construction project, to monitor performance of a project, cross comparison of construction activities. A very important is that project execution team enables the continuous improvement of a project from the implementation stage by using QPAM. By using QPAM to measure quality performance, a project execution team is able to monitor the quality performance against its planned quality. It helps to take informed decisions regarding project cost and time, material inventory etc. to project execution team.

\section{REFERENCES}

[1] Abdul Halim Bin Ahmad (2018). Development and Assessment of e-CQI System. International Journal of Scientific \& Engineering Research.

[2] Ron Basu (2014). Managing quality in projects: An empirical study. International Journal of Project Management.

[3] BCA (Building Construction Authority Singapore) (2012). The BCA construction quality assessment system (CONQUAS). Singapore: Building and Construction Authority.

[4] Ede, A. N. 2011. "Measures to reduce the high incidence of structural failures in Nigeria." J. Sustainable Dev. Africa.

[5] H. Mallawaarachchi and S. Senaratne (2015). Importance of Quality for Construction Project Success. International conference on Structural Engineering and Construction Management.

[6] Mattie J. Haverila and Kacy Fehr (2016). The Impact of Product Superiority on Customer Satisfaction in Project Management.

[7] Hong Yeow Ong, Chen Wang and Nurshuhada Zainon (2018). Developing a Quality embedded EVM tool to facilitate the Iron Triangle in Architectural, Construction and Engineering Practices. Journal of Construction and Management.

[8] Zeljko M. Torbika and Robert C. Storh (1999). Impact of Total Quality Management on HomeBuyer Satisfaction. 